\title{
Longitudinally Extensive Myelitis Associated With Immune Checkpoint Inhibitors
}

Alberto Picca, MD, Giulia Berzero, MD, PhD, Kevin Bihan, PharmD, Vincent Jachiet, MD, Edouard Januel, MD, Marc Coustans, MD, Cecile Cauquil, MD, Julie Perrin, MD, Pablo Berlanga, MD, PhD, Nora Kramkimel, MD, PhD, Bethsabée Garel, MD, Perrine Devic, MD, François Ducray, Marion Benazra, MSc, Flavie Bompaire, MD, Delphine Leclercq, MD, Jean-Marie Michot, MD, PhD, Samy Ammari, MD, and Dimitri Psimaras, MD

Neurol Neuroimmunol Neuroinflamm 2021;8:e967. doi:10.1212/NXI.0000000000000967

\section{Abstract \\ Objective}

To define the characteristics and the outcome of myelitis associated with immune checkpoint inhibitors (ICIs).

\section{Methods}

We performed a retrospective research in the databases of the French Pharmacovigilance Agency and the OncoNeuroTox network for patients who developed myelitis following treatment with ICIs (2011-2020). A systematic review of the literature was performed to identify similar cases.

\section{Results}

We identified 7 patients who developed myelitis after treatment with ICIs (anti-PD1 [n = 6], anti-PD1 + anti-CTLA4 $[\mathrm{n}=1])$. Neurologic symptoms included paraparesis $(100 \%)$, sphincter dysfunction (86\%), tactile/thermic sensory disturbances (71\%), and proprioceptive ataxia $(43 \%)$. At the peak of symptom severity, all patients were nonambulatory. MRI typically showed longitudinally extensive lesions, with patchy contrast enhancement. CSF invariably showed inflammatory findings. Five patients (71\%) had clinical and/or paraclinical evidence of concomitant cerebral, meningeal, caudal roots, and/or peripheral nerve involvement. Despite the prompt discontinuation of ICIs and administration of high-dose glucocorticoids $(n=7)$, most patients needed second-line immune therapies $(n=5)$ because of poor recovery or early relapses. At last follow-up, only 3 patients had regained an ambulatory status (43\%). Literature review identified 13 previously reported cases, showing similar clinical and paraclinical features. All patients discontinued ICIs and received high-dose glucocorticoids, with the addition of other immune therapies in 8 . Clinical improvement was reported for 10 patients.

\section{Conclusion}

Myelitis is a rare but severe complication of ICIs that shows limited response to glucocorticoids. Considering the poor functional outcome associated with longitudinally extensive myelitis, strong and protracted immune therapy combinations are probably needed upfront to improve patient outcome and prevent early relapses.
Correspondence

Dr. Psimaras

dimitri.psimaras@aphp.fr

From the Department of Brain and Behavioral Sciences (A.P., G.B.), University of Pavia, Italy; Regional Pharmacovigilance Center (K.B.), Department of Pharmacology, APHP; APHP (V.J., E.J.), Hôpital Saint-Antoine, Paris; CHI de Cornouaille (M.C.), Quimper; Service de Neurologie (C.C.), Hôpital Bicêtre, AP-HP, Le Kremlin-Bicetre; Hôpitaux Privés de Metz (J.P.), Metz; Gustave Roussy (P.B.), Université Paris-Saclay, Villejuif; Service de Dermatologie (N.K., B.G.), Cochin Hospital AP-HP, Paris; Centre Hospitalier Universitaire Lyon Sud (P.D.), Hospices Civils de Lyon, Pierre-Bénite; Hospices Civils de Lyon (F.D.), Hôpital Neurologique, Bron; Inserm (M.B.), CNRS, UMR S 1127, Institut du Cerveau et de la Moelle épinière (ICM), Paris; OncoNeuroTox Group (F.B.), Hôpital Percy, Clamart; Service de Neuroradiologie (D.L.), AP-HP Pitié-Salpêtrière, Paris; Département d'Innovation Thérapeutique et d'Essais Précoces (J.M.M.), Gustave Roussy, Villejuif; Department of Diagnostic Radiology (S.A.), Gustave Roussy, Villejuif; and Service de Neurologie 2 (D.P.), Groupe Hospitalier Pitié-Salpêtrière, APHP, Paris, France. 


\section{Glossary}

CTLA4 = cytotoxic T-lymphocyte-associated protein 4; ICI = immune checkpoint inhibitor; irAE = immune-related adverse event; NSCLC = non-small-cell lung cancer; PD-1 = programmed death 1 ; PDL-1 = programmed death-ligand 1.

Immune checkpoint inhibitors (ICIs) are monoclonal antibodies used for cancer treatment that enhance host immune responses toward tumor cells by blocking signaling pathways responsible for $\mathrm{T}$ cell inhibition (cytotoxic T-lymphocyte-associated protein 4 [CTLA4], programmed death 1 [PD-1]/programmed deathligand $1\left[\right.$ PDL-1]). ${ }^{1}$ Despite their remarkable oncological efficacy, ${ }^{1}$ ICIs might result in unwanted immune reactions against the self. ${ }^{2}$ Neurologic immune-related adverse events (irAEs) are relatively uncommon, but they might be severely disabling or even life threatening. ${ }^{3}$ Among them, myelitis seems especially rare, its description remaining limited to isolated cases. Here, we present 7 patients with ICI-related myelitis, together with a systematic review of the literature, with the aim to define the core characteristics and the outcome of this rare condition.

\section{Methods}

\section{Present Series}

We performed a retrospective research (July 2011-June 2020) in the database of the French Pharmacovigilance Agency and in the database of the OncoNeuroTox network (French network for neurologic complications from oncologic treatments) for cases of myelitis occurring during ICI treatment. Inclusion criteria comprised (1) symptoms of acute transverse myelitis (i.e., bilateral sensory, motor, or autonomic signs or symptoms attributable to spinal cord involvement, peaking between 4 hours and 21 days), (2) symptom onset within 3 months from the last dose of ICIs, (3) spinal cord lesions on MRI compatible with myelitis, and (4) exclusion of other causes of myelopathy (e.g., vascular, neoplastic, infectious, and compressive) after an extensive workup. Clinical and paraclinical data of the patients included in the study were gathered from referring centers and independently reviewed by 2 investigators (A.P. and D.P.). MRI scans were centrally reviewed by an expert neuroradiologist (S.A.). The French national commission for data protection and liberties approved the use of confidential, electronically processed, patient data (reference number 1922081).

\section{Literature Review}

We conducted a systematic MEDLINE research according to PRISMA guidelines for all articles published in English up to June 2020, reporting cases of myelitis during ICI treatment (appendix e-1, links.lww.com/NXI/A415). We identified 10 articles, reporting as many individual cases meeting the same inclusion criteria established for our series. Three additional cases were identified screening the proceedings of the AAN, EAN, and ECTRIMS congresses (2015-2020).

\section{Data Availability}

Additional data can be made available on request to the authors.

\section{Results}

\section{Present Series}

The main clinical and paraclinical features in our 7 patients are reported in table 1 . The cases of 2 patients (patients \#1, 4) are being submitted elsewhere as separate publications. Patients were receiving anti-PD1 (pembrolizumab $[\mathrm{n}=3]$, nivolumab [n $=3]$ ) or combination treatments (nivolumab plus ipilimumab [n $=1]$ ) because of refractory $(2 / 7,29 \%)$ or metastatic $(5 / 7,71 \%)$ tumors consisting of non-small-cell lung cancer (NSCLC) in 5 cases. Three patients $(3 / 7,43 \%)$ had received thoracic irradiation involving the spinal cord.

Symptoms of myelitis appeared after a median of 7 cycles of ICIs (range 3-51) and included moderate to severe paraparesis $(7 / 7,100 \%)$, sphincter dysfunction $(6 / 7,86 \%)$, tactile and/or thermic sensory deficits $(5 / 7,71 \%)$, and proprioceptive ataxia $(3 / 7,43 \%)$. At the peak of symptom severity, all patients were nonambulatory (median modified Rankin Scale score: 4 ).

Spine MRI showed longitudinally extensive lesions (i.e., $\geq 3$ metameres) in 6 patients $(6 / 7,86 \%)$, often associated with spinal swelling (figure 1). Contrast enhancement was present in 6 cases $(6 / 7,86 \%)$ and was typically focal and patchy. In patients with a history of spinal irradiation, MRI alterations were primarily centered on irradiated metameres, although they clearly exceeded the radiation field.

CSF analysis commonly showed inflammatory changes, including increased proteins $(5 / 6$; median protein levels $1.83 \mathrm{~g} / \mathrm{L}$, range 0.32-5.20 g/L), lymphocytic pleocytosis (4/6; median cell count 97 cells $/ \mathrm{mm}^{3}$, range $3-900 \mathrm{cells} / \mathrm{mm}^{3}$ ), and CSF-specific oligoclonal bands $(3 / 6)$.

Information on CNS autoantibody testing is provided in table e-1, links.lww.com/NXI/A418. One patient tested positive for antiglial fibrillary acidic protein antibodies in the CSF (patient \#4), and 2 showed atypical neuronal reactivities on in-house indirect immunofluorescence on rodent brain sections (patient \#1, 7) (figure e-1, links.lww.com/NXI/A416). Anti-aquaporin-4 and antimyelin oligodendrocyte glycoprotein antibodies were negative in all patients tested.

Besides signs and symptoms of acute transverse myelitis, 5 patients $(5 / 7,71 \%)$ had clinical, neurophysiologic, and/or radiologic evidence of concomitant brain (patients 4, 6, and 7) (figure 1), meningeal (patients 4 and 7), radicular (patients 1,3, 6 , and 7), and/or peripheral nerve (patient 6) involvement.

All patients discontinued ICI treatment at myelitis diagnosis and received high-dose glucocorticoids, associated with 
Table 1 Clinical and Paraclinical Features, Treatment, and Outcome in the 7 Cases of Myelitis Associated With ICI From Our Series

\begin{tabular}{|c|c|c|c|}
\hline & Patient 1 & Patient 2 & Patient 3 \\
\hline Age at myelitis onset/sex & $57 / \mathrm{M}$ & $62 / F$ & $16 / F$ \\
\hline Malignancy & NSCLC & NSCLC & Mesenteric IMT \\
\hline $\begin{array}{l}\text { Previous RT involving the } \\
\text { spinal cord }\end{array}$ & $\begin{array}{l}\text { Thoracic ( } 66 \mathrm{~Gy} / 33 \mathrm{fr} \text { ), } \\
13 \text { mo before onset }\end{array}$ & $\begin{array}{l}\text { T4 vertebral body, } \\
13 \text { mo before onset }\end{array}$ & No \\
\hline $\mathrm{ICI}$ received (cycles) & Nivolumab (12) & Nivolumab (7) & Pembrolizumab (19) \\
\hline Neurologic syndrome & Myeloradiculitis & Myelitis & Myeloradiculitis \\
\hline Clinical presentation & $\begin{array}{l}\text { Severe paraparesis, } \\
\text { neuropathic pain, and } \\
\text { sphincter dysfunction }\end{array}$ & $\begin{array}{l}\text { Severe paraparesis, } \\
\text { sensory impairment } \\
\text { with T11 level, and } \\
\text { fecal and urinary } \\
\text { incontinence }\end{array}$ & $\begin{array}{l}\text { Moderate paraparesis, } \\
\text { gait ataxia, sensory } \\
\text { impairment with T6 } \\
\text { level, radicular pain, } \\
\text { and bladder dysfunction }\end{array}$ \\
\hline mRS at symptom nadir & 4 & 5 & 4 \\
\hline CSF cells $(n / \mu L)$ & 88 & NA & 3 \\
\hline CSF proteins(g/L) & 3.76 & NA & 0.32 \\
\hline CSF-restricted OCB & Yes & NA & NA \\
\hline CNS autoantibodies & $\begin{array}{l}\text { Atypical antibody } \\
\text { reactivity on rodent } \\
\text { sections }\end{array}$ & NA & NA \\
\hline Spine MRI findings & $\begin{array}{l}\text { Multiple T2 } \\
\text { hyperintensities } \\
\text { at C7-T4 and T11-T12 } \\
\text { with associated CE at C7-T2 } \\
\text { and T11-T12; CE of filum } \\
\text { terminale and caudal roots }\end{array}$ & $\begin{array}{l}\text { Whole-spine T2 } \\
\text { hyperintensity with } \\
\text { focal CE T4-T6 }\end{array}$ & $\begin{array}{l}\text { Multiple T2 } \\
\text { hyperintensities } \\
\text { C4-C5, C7-T3, and T9-T12 } \\
\text { with anterior patchy CE }\end{array}$ \\
\hline Brain MRI findings & Unremarkable & $\begin{array}{l}\text { Stable known brain } \\
\text { metastases and } \\
\text { radiation-induced } \\
\text { leukoencephalopathy }\end{array}$ & Unremarkable \\
\hline First-line treatment & $\begin{array}{l}\text { Oral prednisone } \\
\text { ( } 1 \mathrm{mg} / \mathrm{kg} / \mathrm{die}) \text { tapered } \\
\text { over } 4 \mathrm{mo}\end{array}$ & IV MP & $\begin{array}{l}\text { IV MP followed by } \\
\text { oral tapering } \\
\text { (from } 1 \mathrm{mg} / \mathrm{kg} / \mathrm{die} \text { ) }\end{array}$ \\
\hline Myelitis relapse & $\begin{array}{l}\text { Yes ( } 3 \text { weeks after the } \\
\text { end of steroid tapering) }\end{array}$ & No & No \\
\hline Second-line treatments & $\begin{array}{l}\text { IV MP + PLEX (7 sessions) } \\
+ \text { monthly IV CP }(\times 2)\end{array}$ & No & No \\
\hline Outcome at last follow-up & $\begin{array}{l}\text { Persistent severe } \\
\text { paraparesis }\end{array}$ & Death due to sepsis & Complete recovery \\
\hline mRS score at last follow-up & 4 & 6 & 0 \\
\hline $\begin{array}{l}\text { Follow-up from } \\
\text { myelitis onset (mo) }\end{array}$ & 18 & 2 & 15 \\
\hline
\end{tabular}

Abbreviations: $C E=$ contrast enhancement, $C P=$ cyclophosphamide, fr = fractions, Gy = gray, ICI = immune checkpoint inhibitor, IMT = inflammatory myofibroblastic tumor, IVIG = IV immunoglobulin, MP = methylprednisolone, mRS = modified Rankin Scale, NA = not available, NSCLC = non-small-cell lung cancer, OCB = oligoclonal bands, PLEX = plasmapheresis, RT = radiotherapy.

plasmapheresis in 1 (patient 4). One patient experienced a significant and sustained clinical benefit (patient 3 ), whereas 5 patients had to shift to second-line treatments because of poor recovery (patients 4,5 , and 7 ) or an early relapse at steroid tapering (patients 1 and 6; table 1). Second-line agents were started after a median of 20 days from symptom onset and included plasmapheresis $(\mathrm{n}=3)$, cyclophosphamide $(\mathrm{n}=2)$, IV immunoglobulin (IVIg, $\mathrm{n}=1)$, natalizumab $(\mathrm{n}=1)$, and an association of tocilizumab and ruxolitinib $(\mathrm{n}=1)$. At last followup, a median of 6 months after diagnosis, only 3 patients had regained an ambulatory status $(3 / 7,43 \%)$. None of the patients was rechallenged with ICIs.

\section{Literature Review}

Our systematic literature review identified 13 previously published cases. ${ }^{\text {el-e13 }}$ Clinical and paraclinical features were 
Table 1 (continued)

\begin{tabular}{|c|c|c|c|}
\hline Patient 4 & Patient 5 & Patient 6 & Patient 7 \\
\hline $59 / M$ & $61 / F$ & $57 / M$ & $58 / \mathrm{M}$ \\
\hline NSCLC & NSCLC & NSCLC & Melanoma \\
\hline No & No & $\begin{array}{l}\text { Mediastinal } \\
\text { ( } 66 \mathrm{~Gy} / 33 \mathrm{fr}), 13 \mathrm{mo} \\
\text { before onset }\end{array}$ & No \\
\hline Pembrolizumab (5) & Pembrolizumab (5) & Nivolumab (51) & $\begin{array}{l}\text { Ipilimumab + } \\
\text { nivolumab (4) }\end{array}$ \\
\hline Meningoencephalomyelitis & Myelitis & $\begin{array}{l}\text { Encephalomyelitis } \\
\text { and demyelinating } \\
\text { polyradiculoneuritis }\end{array}$ & $\begin{array}{l}\text { Meningoencephalo- } \\
\text { myeloradiculitis }\end{array}$ \\
\hline $\begin{array}{l}\text { Severe tetraparesis, bladder } \\
\text { dysfunction, neck stiffness, } \\
\text { neuropathic pain, dysphagia, } \\
\text { and altered consciousness }\end{array}$ & $\begin{array}{l}\text { Moderate to severe } \\
\text { paraparesis, left upper } \\
\text { limb weakness, } \\
\text { proprioceptive ataxia, } \\
\text { and lower limb numbness }\end{array}$ & $\begin{array}{l}\text { Severe paraparesis, } \\
\text { proprioceptive ataxia, } \\
\text { sensory impairment } \\
\text { with T12 level, radicular } \\
\text { pain, and bladder } \\
\text { hyperactivity }\end{array}$ & $\begin{array}{l}\text { Paraplegia, sensory } \\
\text { impairment with T10 } \\
\text { level, lower limb areflexia, } \\
\text { and fecal and urinary retention }\end{array}$ \\
\hline 5 & 4 & 4 & 4 \\
\hline 900 & 105 & 5 & 115 \\
\hline 5.2 & 0.75 & 1.09 & 2.57 \\
\hline NA & Yes & Yes & No \\
\hline Anti-GFAP antibodies & No & No & $\begin{array}{l}\text { Atypical antibody reactivity } \\
\text { on rodent sections }\end{array}$ \\
\hline $\begin{array}{l}\text { T2 hyperintensity from } \\
\text { C1 to T10; CE of spinal } \\
\text { leptomeninges }\end{array}$ & $\begin{array}{l}\text { Focal T2 hyperintensity } \\
\text { C3-C } 4 \text { without CE }\end{array}$ & $\begin{array}{l}\text { Multiple T2 } \\
\text { hyperintensities at } \\
\text { C3-C6, T2-T3, T8-T11 with } \\
\text { faint CE at T8-T11; CE of } \\
\text { caudal roots }\end{array}$ & $\begin{array}{l}\text { Multiple T2 } \\
\text { hyperintensities at } \\
\text { C2, C3, C7-T2, T4-T7, } \\
\text { T8-conus with associated } \\
\text { patchy CE; CE of spinal } \\
\text { leptomeninges and } \\
\text { caudal roots }\end{array}$ \\
\hline $\begin{array}{l}\text { Faint periventricular } \\
\text { CE with radial, linear pattern; } \\
\text { leptomeningeal CE; bulbar T2 } \\
\text { hyperintensity }\end{array}$ & $\begin{array}{l}\text { Stable known brain } \\
\text { metastasis }\end{array}$ & $\begin{array}{l}\text { Multiple periventricular, } \\
\text { thalamocapsular and right } \\
\text { fronto-insular cortex T2 } \\
\text { hyperintensities without CE }\end{array}$ & $\begin{array}{l}\text { Multiple bilateral } \\
\text { brain hemispheric and } \\
\text { cerebellar punctiform, } \\
\text { faint CE }\end{array}$ \\
\hline $\begin{array}{l}\text { IV MP + PLEX (15 sessions), } \\
\text { oral prednisone ( } 2 \mathrm{mg} / \mathrm{kg} / \mathrm{die} \text { ) } \\
\text { tapered over } 2 \mathrm{mo}\end{array}$ & $\begin{array}{l}\text { IV MP followed by oral } \\
\text { prednisone tapering }\end{array}$ & $\begin{array}{l}\text { IV MP followed by } \\
\text { prednisone ( } 1 \mathrm{mg} / \mathrm{kg} / \mathrm{die}) \\
\text { tapered over } 6 \mathrm{wk}\end{array}$ & $\begin{array}{l}\text { IV MP, oral prednisone } \\
\text { tapering (from } \\
1 \mathrm{mg} / \mathrm{kg} / \mathrm{die} \text {, ongoing) }\end{array}$ \\
\hline No & No & $\begin{array}{l}\text { Yes ( } 2 \text { weeks after } \\
\text { the end of the steroid } \\
\text { tapering) }\end{array}$ & No \\
\hline Natalizumab (x1) & Monthly IV CP (×6) & $\begin{array}{l}\text { Monthly IVIG }(\times 3) \text { and } \\
\text { PLEX ( } 5 \text { sessions) }\end{array}$ & $\begin{array}{l}\text { PLEX (1 session), } \\
\text { tocilizumab }(\times 2)+ \\
\text { ruxolitinib }(23 \text { days })\end{array}$ \\
\hline $\begin{array}{l}\text { Persistent bladder } \\
\text { disorder with need of } \\
\text { intermittent urinary } \\
\text { catheterization }\end{array}$ & $\begin{array}{l}\text { Persistent disabling } \\
\text { left arm and leg weakness } \\
\text { and severe proprioceptive } \\
\text { ataxia }\end{array}$ & $\begin{array}{l}\text { Persistent leg weakness } \\
\text { and hypesthesia and } \\
\text { persistent disabling pain }\end{array}$ & $\begin{array}{l}\text { Persistent leg weakness } \\
\text { and hypesthesia, urinary } \\
\text { retention, and fecal } \\
\text { incontinence }\end{array}$ \\
\hline 2 & 4 & 4 & 3 \\
\hline 6 & 6 & 6 & 5 \\
\hline
\end{tabular}

similar to patients in our series (table 2), with contrastenhancing longitudinally extensive lesions on MRI and inflammatory findings on CSF analysis. Four patients had positive CNS autoantibodies, including 2 with anti- aquaporin-4 antibodies. ${ }^{\text {e3,es,e9,e11 }}$ All patients discontinued ICIs and received high-dose glucocorticoids, alone $(8 / 13$, $62 \%)$ or in association with other immune therapies $(5 / 13$, $38 \%)$. Three patients $(3 / 13,23 \%)$ shifted to second-line 

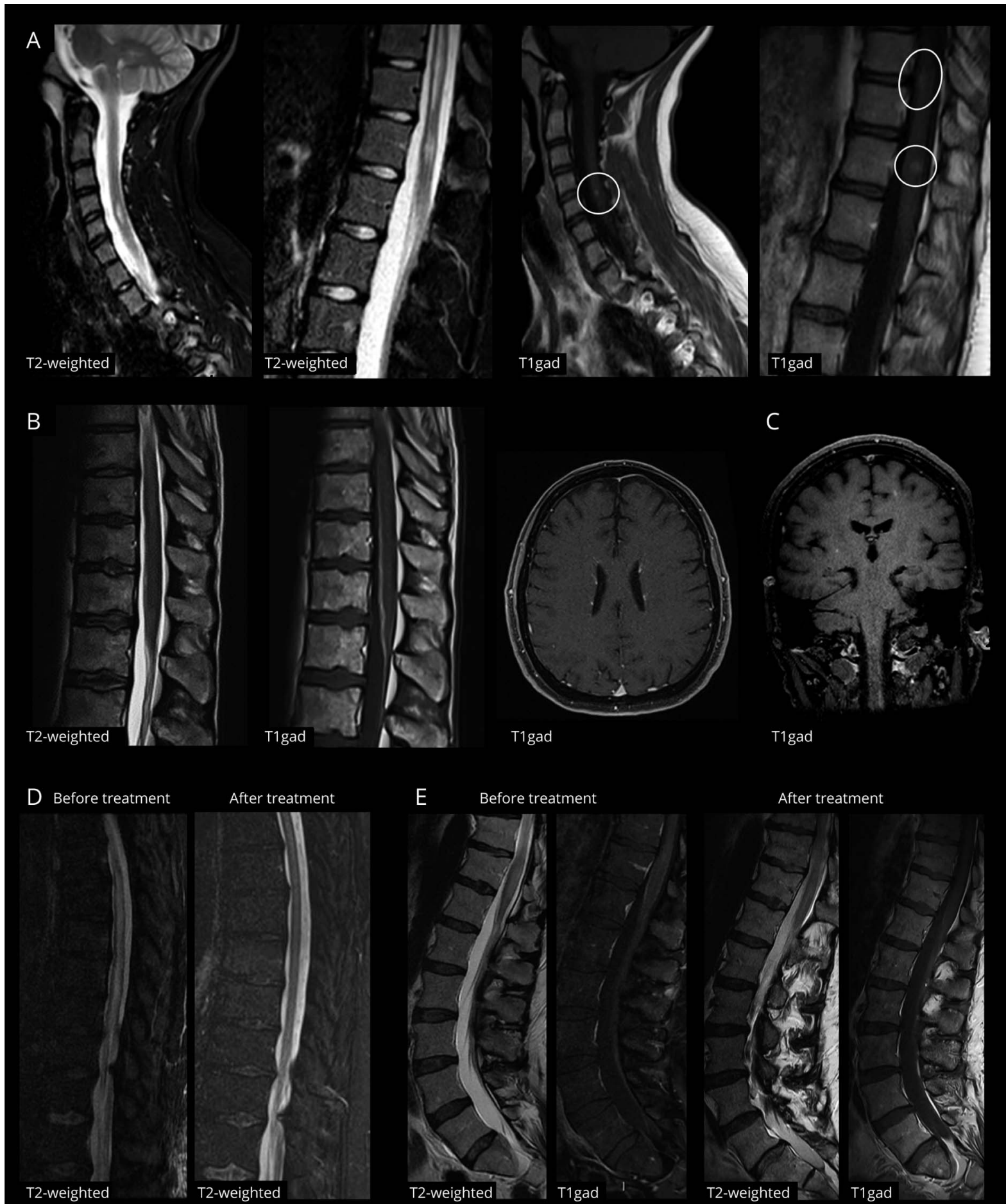

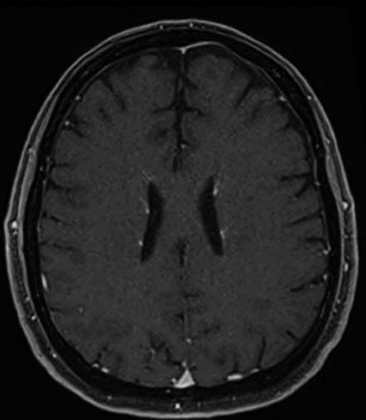

T1gad

T1gad

(A) Spinal MRI at diagnosis in patient 3, showing multiple hyperintensities at C4-C5, T9-T11, and T12 on sagittal T2/STIR sequences, with focal areas of contrast enhancement on T1 sequences after gadolinium injection (circles). (B) Spinal and brain MRI at diagnosis in patient 4, who had positive antibodies to glial fibrillary acidic protein. Spinal MRI showed a faint hyperintensity at T10-T12 on T2/STIR sequences and a marked contrast enhancement of the anterior portion of the dural sac and of filum terminale on T1 sequences after gadolinium injection. Brain MRI in the same patient showed linear rims of contrast enhancement expanding radially from lateral ventricles. (C) Brain MRI at diagnosis in patient 7 showing small punctuate areas of contrast enhancement in bilateral subcortical and deep white matter, without corresponding signal alterations on FLAIR sequences (not shown). (D) Control spinal MRI of the thoracic tract (sagittal T2/STIR sequences) in patient 1,15 days after starting treatment with high-dose glucocorticoids and plasmapheresis, showing an almost complete resolution of the longitudinally extensive hyperintensity of the spinal cord compared with initial imaging. (E) Control spinal MRI of the lumbar tract (sagittal T2/STIR and T1 sequences after gadolinium injection) in patient 7, 15 days after starting treatment with high-dose glucocorticoids, plasmapheresis, tocilizumab, and ruxolitinib, showing a marked reduction of the hyperintensity and swelling of the conus and of the associated leptomeningeal and caudal root enhancement compared with initial imaging. $\mathrm{ICI}=$ immune checkpoint inhibitor. 
Table 2 Main Clinical and Paraclinical Features in Patients With Acute Transverse Myelitis During ICI Treatment From Our Present Series and Literature Review

\begin{tabular}{|c|c|c|}
\hline & Present series & Literature review \\
\hline $\mathbf{N}$ & 7 & 13 \\
\hline Age at myelitis onset, median (range) & $58(16-62)$ & $63(35-75)$ \\
\hline Sex ratio (male/female) & $1.33(4 / 3)$ & $1.60(8 / 5)$ \\
\hline Malignancy, n (\%) & $\begin{array}{l}\text { NSCLC, } 5 / 7(71 \%) \\
\text { Melanoma, } 1 / 7(14 \%) \\
\text { Mesenteric IMT, } 1 / 7(14 \%)\end{array}$ & $\begin{array}{l}\text { Melanoma, } 6 / 13(46 \%) \\
\text { NSCLC, } 4 / 13(31 \%) \\
\text { Others, } 3 / 13(23 \%)^{\mathrm{a}}\end{array}$ \\
\hline Previous RT involving the spinal cord, $\mathbf{n}(\%)$ & $3 / 7(43 \%)$ & $3 / 13(23 \%)$ \\
\hline ICI treatment, $\mathrm{n}(\%)$ & $\begin{array}{l}\text { Anti-PD1, } 6 / 7(86 \%) \\
\quad \text { Nivolumab, } n=3 \\
\text { Pembrolizumab, } n=3 \\
\text { Anti-PD1 + anti-CTLA4, } 1 / 7 \text { (14\%) }\end{array}$ & $\begin{array}{l}\text { Anti-PD1, } 5 / 13(38 \%) \\
\text { Pembrolizumab, } \mathrm{n}=3^{\mathrm{b}} \\
\text { Nivolumab, } \mathrm{n}=2 \\
\text { Anti-PDL1, } 2 / 13(15 \%) \\
\text { Atezolizumab, } \mathrm{n}=1 \\
\text { Durvalumab, } \mathrm{n}=1 \\
\text { Anti-CTLA4, } 2 / 13(15 \%) \\
\text { Ipilimumab, } \mathrm{n}=3^{\mathrm{c}} \\
\text { Anti-PD1 + anti-CTLA4, 2/13 (15\%) }\end{array}$ \\
\hline $\begin{array}{l}\text { Number of ICI cycles received, median } \\
\text { (range) }\end{array}$ & $7(3-51)$ & $3(1-16)$ \\
\hline Symptoms, n (\%) & $\begin{array}{l}\text { Paraparesis, } 7 / 7(100 \%) \\
\text { Sphincter dysfunction, } 6 / 7(86 \%) \\
\text { Tactile/thermic sensory deficits, 5/7 (71\%) } \\
\text { Proprioceptive ataxia, 3/7 (43\%) }\end{array}$ & $\begin{array}{l}\text { Paraparesis, 12/13 (92\%) } \\
\text { Sensory disturbances, 12/13 (92\%) } \\
\text { Sphincter dysfunction, 12/13 (92\%) }\end{array}$ \\
\hline Spine MRI findings, $\mathbf{n}(\%)$ & $\begin{array}{l}\text { T2 hypersignal extending for } \geq 3 \text { metameres, } 6 / 7 \\
(86 \%) \\
\text { Parenchymal enhancement, } 6 / 7 \text { (86\%) }\end{array}$ & $\begin{array}{l}\text { T2 hypersignal extending for } \geq 3 \text { metameres, } 12 / 13 \\
(92 \%) \\
\text { Parenchymal enhancement, } 8 / 8(100 \%)\end{array}$ \\
\hline CSF findings, $\mathbf{n}(\%)$ & $\begin{array}{l}\text { Increased proteins, 5/6 (83\%) } \\
\text { Increased cell count, 4/6 (67\%) }\end{array}$ & $\begin{array}{l}\text { Increased proteins, } 9 / 10(90 \%) \\
\text { Increased cell count, } 9 / 10(90 \%)\end{array}$ \\
\hline $\begin{array}{l}\text { Involvement of other nervous structures, } \mathbf{n} \\
\text { (\%) }\end{array}$ & $5 / 7(71 \%)$ & $2 / 13(15 \%)$ \\
\hline Autoantibodies, $n$ & $\begin{array}{l}\text { Anti-GFAP, } n=1 \\
\text { To unknown CNS antigens, } n=2\end{array}$ & $\begin{array}{l}\text { Anti-AQP4, } \mathrm{n}=2^{\mathrm{e} 3, \mathrm{e} 9} \\
\text { Anti-CV2, } \mathrm{n}=1^{\mathrm{e} 11} \\
\text { To unknown antigen with an AQP4-like pattern, } \mathrm{n}= \\
1^{\mathrm{e} 5}\end{array}$ \\
\hline $\begin{array}{l}\text { First-line treatment, } \\
\mathrm{n}(\%)\end{array}$ & $\begin{array}{l}\text { High-dose glucocorticoids, } 7 / 7 \text { (100\%) } \\
\text { Plus plasmapheresis, } n=1\end{array}$ & $\begin{array}{l}\text { High dose glucocorticoids, 13/13 (100\%) } \\
\text { Plus plasmapheresis, } n=3 \\
\text { Plus other treatment, } n=4^{d}\end{array}$ \\
\hline $\begin{array}{l}\text { Second-line treatments, } \\
\mathrm{n}(\%)\end{array}$ & $\begin{array}{l}\text { Yes, } 5 / 7(71 \%) \\
\text { Plasmapheresis, } n=3 \\
\text { Cyclophosphamide, } n=2 \\
\text { IVIG, } n=1 \\
\text { Natalizumab, } n=1 \\
\text { Tocilizumab plus ruxolitinib, } n=1\end{array}$ & $\begin{array}{l}\text { Yes, } 3 / 13(23 \%) \\
\text { Infliximab, } \mathrm{n}=2 \\
\text { Plasmapheresis, } \mathrm{n}=2 \\
\text { Cyclophosphamide, } \mathrm{n}=1\end{array}$ \\
\hline Myelitis relapse, $\mathrm{n}(\%)$ & $2 / 7(29 \%)$ & $2 / 13(15 \%)$ \\
\hline Outcome & $\begin{array}{l}\text { Clinical improvement, } 2 / 7(29 \%) \\
\text { No improvement, } 4 / 7(57 \%) \\
\text { Death due to sepsis, } 1 / 7(14 \%)\end{array}$ & $\begin{array}{l}\text { Clinical improvement, 10/13 (77\%) } \\
\text { No improvement, 3/13 (23\%) }\end{array}$ \\
\hline
\end{tabular}

Abbreviations: GFAP = glial fibrillary acidic protein; ICI = immune checkpoint inhibitor, IVIG = IV immunoglobulin, NSCLC = non-small-cell lung cancer, RT = radiation therapy.

a Others included Hodgkin lymphoma, renal cell carcinoma, and small-cell lung cancer.

b One patient under pembrolizumab previously received ipilimumab plus nivolumab.

c One patient under ipilimumab previously received nivolumab.

${ }^{d}$ Other treatments included IVIG, cyclophosphamide, rituximab, and bevacizumab (one case each).

treatments, including infliximab $(\mathrm{n}=2)$, plasmapheresis $(\mathrm{n}=$ $2)$, and cyclophosphamide $(\mathrm{n}=1)$. Clinical improvement was reported for 10 patients $(10 / 13,77 \%), 7$ being ambulatory at last follow-up (7/9, 78\%). Relapses were observed in 2 cases $(2 / 13,15 \%) .^{\mathrm{e}-7, \mathrm{e} 13}$ A single patient was rechallenged with ICIs, with no additional toxicity. ${ }^{\mathrm{e} 8}$ 


\section{Discussion}

Here, we reported 7 patients developing acute transverse myelitis following ICI treatment, which were identified through an extensive research in 2 independent national databases. Despite the limitations inherent to the retrospective nature of our methodology and the potential biases related to spontaneous notification, ${ }^{4}$ we could estimate that during the evaluated time frame, over 38,000 patients were treated with ICIs in France outside of clinical trials, making of ICI-related myelitis an extremely rare irAE.

Most patients in our series were affected by NSCLC, and almost half had received thoracic radiotherapy. Besides representing one of the most common indications to ICI treatment, NSCLC often requires the administration of local radiotherapy, which invariably delivers a dose to the spinal cord. By potentiating the immune responses elicited by ICIs, ${ }^{5}$ radiotherapy might indeed represent a predisposing factor to the development of myelitis.

Differently from other neurologic irAEs, myelitis was not invariably an early event. Clinical presentation was typical of acute transverse myelitis and was accompanied by inflammatory CSF findings and longitudinally extensive lesions on MRI. Of interest, in most cases, inflammatory changes extended to the brain parenchyma, the leptomeninges and caudal nerve roots, suggesting that it often exists a broader involvement of the nervous system that might have been underestimated in previous reports. A single patient in our series tested positive for known antibodies to neural antigens, although we recognize that screening for CNS antibodies was not always exhaustive (table e-1, links.lww.com/NXI/A418).

All patients in our series and in the literature received highdose glucocorticoids as first-line treatment, as recommended by current guidelines, ${ }^{6}$ although most of them ultimately needed additional immune therapies because of the lack of functional improvement. This observation suggests that patients with longitudinally extensive myelitis might benefit from stronger upfront immune therapy schemes, as advocated for other threatening irAEs such as the myositis-myocarditis complex. ${ }^{7}$ Despite some data raised concern, ${ }^{8}$ glucocorticoid treatment does not seem to impair tumor control or patient survival $^{9}$ and should be continued for at least 2 months ${ }^{6}$ to substantiate recovery and prevent early relapses. ${ }^{10}$ Targeted biological agents, such as natalizumab or tocilizumab, which have recently been experimented in this and other settings, ${ }^{7}$ should help to improve therapeutic results, without a risk of interfering with the antitumor activity of ICIs.

\section{Acknowledgment}

This publication uses data collected from all Regional Centers of Pharmacovigilance-organized in a French network of CRPV. The views expressed in this article are those of the authors and do not necessarily represent the ANSM position of the UMC or the World Health Organization. The information comes from a variety of sources, and the probability that the suspected adverse effect is drug related is not the same in all cases.

\section{Study Funding}

The authors report no targeted funding.

\section{Disclosure}

Go to Neurology.org/NN for full disclosures.

\section{Publication History}

Received by Neurology: Neuroimmunology \& Neuroinflammation October 26, 2020. Accepted in final form January 7, 2021.

Appendix 1 Authors

\begin{tabular}{|c|c|c|}
\hline Name & Location & Contribution \\
\hline $\begin{array}{l}\text { Alberto } \\
\text { Picca, MD }\end{array}$ & $\begin{array}{l}\text { Groupe Hospitalier Pitié- } \\
\text { Salpêtrière, Paris, France; } \\
\text { University of Pavia, Italy }\end{array}$ & $\begin{array}{l}\text { Designed and } \\
\text { conceptualized the study; } \\
\text { analyzed the data; and } \\
\text { drafted the manuscript } \\
\text { for intellectual content }\end{array}$ \\
\hline $\begin{array}{l}\text { Giulia } \\
\text { Berzero, } \\
\text { MD, PhD }\end{array}$ & $\begin{array}{l}\text { Groupe Hospitalier Pitié- } \\
\text { Salpêtrière, Paris, France; } \\
\text { University of Pavia, Italy }\end{array}$ & $\begin{array}{l}\text { Designed and } \\
\text { conceptualized the study; } \\
\text { analyzed the data; and } \\
\text { drafted the manuscript for } \\
\text { intellectual content }\end{array}$ \\
\hline $\begin{array}{l}\text { Kevin } \\
\text { Bihan, } \\
\text { PharmD }\end{array}$ & $\begin{array}{l}\text { Groupe Hospitalier Pitié- } \\
\text { Salpêtrière, Paris, France }\end{array}$ & $\begin{array}{l}\text { Designed and } \\
\text { conceptualized the study; } \\
\text { analyzed the data; and } \\
\text { drafted the manuscript } \\
\text { for intellectual content }\end{array}$ \\
\hline $\begin{array}{l}\text { Vincent } \\
\text { Jachiet, MD }\end{array}$ & $\begin{array}{l}\text { Hôpital Saint-Antoine, } \\
\text { Paris, France }\end{array}$ & $\begin{array}{l}\text { Interpreted the data; major } \\
\text { role in the acquisition of } \\
\text { data; and revised the } \\
\text { manuscript for intellectual } \\
\text { content }\end{array}$ \\
\hline $\begin{array}{l}\text { Edouard } \\
\text { Januel, MD }\end{array}$ & $\begin{array}{l}\text { Hôpital Saint-Antoine, } \\
\text { Paris, France }\end{array}$ & $\begin{array}{l}\text { Major role in the } \\
\text { acquisition of data and } \\
\text { revised the manuscript } \\
\text { for intellectual content }\end{array}$ \\
\hline $\begin{array}{l}\text { Marc } \\
\text { Coustans, } \\
\text { MD }\end{array}$ & $\begin{array}{l}\text { Centre Hospitalier de } \\
\text { Quimper, France }\end{array}$ & $\begin{array}{l}\text { Major role in the } \\
\text { acquisition of data and } \\
\text { revised the manuscript for } \\
\text { intellectual content }\end{array}$ \\
\hline $\begin{array}{l}\text { Cécile } \\
\text { Cauquil, MD }\end{array}$ & $\begin{array}{l}\text { Hôpital Bicêtre, Le Kremlin- } \\
\text { Bicêtre, France }\end{array}$ & $\begin{array}{l}\text { Major role in the } \\
\text { acquisition of data and } \\
\text { revised the manuscript for } \\
\text { intellectual content }\end{array}$ \\
\hline $\begin{array}{l}\text { Julie Perrin, } \\
\text { MD }\end{array}$ & $\begin{array}{l}\text { Hôpitaux Privés de Metz, } \\
\text { Metz, France }\end{array}$ & $\begin{array}{l}\text { Major role in the } \\
\text { acquisition of data and } \\
\text { revised the manuscript for } \\
\text { intellectual content }\end{array}$ \\
\hline $\begin{array}{l}\text { Pablo } \\
\text { Berlanga, } \\
\text { MD, PhD }\end{array}$ & $\begin{array}{l}\text { Gustave Roussy, Villejuif, } \\
\text { France }\end{array}$ & $\begin{array}{l}\text { Major role in the } \\
\text { acquisition of data and } \\
\text { revised the manuscript for } \\
\text { intellectual content }\end{array}$ \\
\hline $\begin{array}{l}\text { Nora } \\
\text { Kramkimel, } \\
\text { MD, PhD }\end{array}$ & $\begin{array}{l}\text { Hôpital Cochin, Paris, } \\
\text { France }\end{array}$ & $\begin{array}{l}\text { Major role in the } \\
\text { acquisition of data and } \\
\text { revised the manuscript for } \\
\text { intellectual content }\end{array}$ \\
\hline
\end{tabular}

Continued 
Appendix 1 (continued)

\begin{tabular}{|c|c|c|}
\hline Name & Location & Contribution \\
\hline $\begin{array}{l}\text { Bethsabée } \\
\text { Garel, MD }\end{array}$ & $\begin{array}{l}\text { Hôpital Cochin, Paris, } \\
\text { France }\end{array}$ & $\begin{array}{l}\text { Major role in the } \\
\text { acquisition of data and } \\
\text { revised the manuscript for } \\
\text { intellectual content }\end{array}$ \\
\hline $\begin{array}{l}\text { Perrine } \\
\text { Devic, MD }\end{array}$ & $\begin{array}{l}\text { Centre Hospitalier } \\
\text { Universitaire Lyon Sud, } \\
\text { Pierre-Bénite, France }\end{array}$ & $\begin{array}{l}\text { Major role in the } \\
\text { acquisition of data and } \\
\text { revised the manuscript for } \\
\text { intellectual content }\end{array}$ \\
\hline $\begin{array}{l}\text { François } \\
\text { Ducray }\end{array}$ & $\begin{array}{l}\text { Hôpital Neurologique } \\
\text { Pierre Wertheimer, Bron, } \\
\text { France }\end{array}$ & $\begin{array}{l}\text { Major role in the } \\
\text { acquisition of data and } \\
\text { revised the manuscript for } \\
\text { intellectual content }\end{array}$ \\
\hline $\begin{array}{l}\text { Marion } \\
\text { Benazra, } \\
\text { MSc }\end{array}$ & $\begin{array}{l}\text { Institut du Cerveau et de la } \\
\text { Moelle épinière, Paris, } \\
\text { France }\end{array}$ & $\begin{array}{l}\text { Performed and interpreted } \\
\text { the immunohistochemical } \\
\text { analyses and revised the } \\
\text { manuscript for intellectual } \\
\text { content }\end{array}$ \\
\hline $\begin{array}{l}\text { Flavie } \\
\text { Bompaire, } \\
\text { MD }\end{array}$ & $\begin{array}{l}\text { Hôpital D'Instruction Des } \\
\text { Armées Percy, Clamart, } \\
\text { France }\end{array}$ & $\begin{array}{l}\text { Major role in the } \\
\text { acquisition of data and } \\
\text { revised the manuscript for } \\
\text { intellectual content }\end{array}$ \\
\hline $\begin{array}{l}\text { Delphine } \\
\text { Leclercq, } \\
\text { MD }\end{array}$ & $\begin{array}{l}\text { Groupe Hospitalier Pitié- } \\
\text { Salpêtrière, Paris, France }\end{array}$ & $\begin{array}{l}\text { Performed and interpreted } \\
\text { the radiologic analyses and } \\
\text { revised the manuscript for } \\
\text { intellectual content }\end{array}$ \\
\hline $\begin{array}{l}\text { Jean-Marie } \\
\text { Michot, MD, } \\
\text { PhD }\end{array}$ & $\begin{array}{l}\text { Gustave Roussy, Villejuif, } \\
\text { France }\end{array}$ & $\begin{array}{l}\text { Major role in the } \\
\text { acquisition of data and } \\
\text { revised the manuscript for } \\
\text { intellectual content }\end{array}$ \\
\hline $\begin{array}{l}\text { Samy } \\
\text { Ammari, } \\
\text { MD }\end{array}$ & $\begin{array}{l}\text { Gustave Roussy, Villejuif, } \\
\text { France }\end{array}$ & $\begin{array}{l}\text { Performed and interpreted } \\
\text { the radiologic analyses and } \\
\text { revised the manuscript for } \\
\text { intellectual content }\end{array}$ \\
\hline
\end{tabular}

Appendix 1 (continued)

\begin{tabular}{|c|c|c|}
\hline Name & Location & Contribution \\
\hline $\begin{array}{l}\text { Dimitri } \\
\text { Psimaras, } \\
\text { MD }\end{array}$ & $\begin{array}{l}\text { Groupe Hospitalier Pitié- } \\
\text { Salpêtrière, Paris, France; } \\
\text { OncoNeuroTox Group, } \\
\text { Paris, France }\end{array}$ & $\begin{array}{l}\text { Designed and } \\
\text { conceptualized } \\
\text { the study; major role } \\
\text { in the acquisition of data; } \\
\text { analyzed the data; and } \\
\text { drafted the manuscript for } \\
\text { intellectual content }\end{array}$ \\
\hline
\end{tabular}

\section{References}

1. Ribas A, Wolchok JD. Cancer immunotherapy using checkpoint blockade. Science 2018;359:1350-1355.

2. Postow MA, Sidlow R, Hellmann MD. Immune-related adverse events associated with immune checkpoint blockade. N Engl J Med 2018;378:158-168.

3. Touat M, Talmasov D, Ricard D, Psimaras D. Neurological toxicities associated with immune-checkpoint inhibitors. Curr Opin Neurol 2017;30: $659-668$.

4. Bihan K, Lebrun-Vignes B, Funck-Brentano C, Salem JE. Uses of pharmacovigilance databases: an overview. Therapie 2020;75:591-598.

5. Hwang WL, Pike LRG, Royce TJ, Mahal BA, Loeffler JS. Safety of combining radiotherapy with immune-checkpoint inhibition. Nat Rev Clin Oncol 2018;15: 477-494.

6. National Comprehensive Cancer Network (NCCN). Clinical Practice Guidelines in Oncology. Management of Immunotherapy-Related Toxicities. Version 1.2020 Available at: nccn.org/professionals/physician_gls/default.aspx. Accessed September 20, 2020.

7. Esfahani K, Elkrief A, Calabrese C, et al. Moving towards personalized treatments of immune-related adverse events. Nat Rev Clin Oncol 2020;17:504-515.

8. Faje AT, Lawrence D, Flaherty K, et al. High-dose glucocorticoids for the treatment of ipilimumab-induced hypophysitis is associated with reduced survival in patients with melanoma. Cancer 2018;124:3706-3714.

9. Petrelli F, Signorelli D, Ghidini M, et al. Association of steroids use with survival in patients treated with immune checkpoint inhibitors: a systematic review and metaanalysis. Cancers 2020;12:546.

10. Bruna J, Argyriou AA, Anastopoulou GG, et al. Incidence and characteristics of neurotoxicity in immune checkpoint inhibitors with focus on neuromuscular events: experience beyond the clinical trials. J Peripher Nerv Syst 2020;25: $171-177$.

Additional e-references e1-e13 available at: links.lww.com/NXI/A417. 


\section{Neurology \\ Neuroimmunology \& Neuroinflammation}

\section{Longitudinally Extensive Myelitis Associated With Immune Checkpoint Inhibitors Alberto Picca, Giulia Berzero, Kevin Bihan, et al. \\ Neurol Neuroimmunol Neuroinflamm 2021;8; \\ DOI 10.1212/NXI.0000000000000967}

This information is current as of February 26, 2021

\section{Updated Information \& Services}

References

Citations

Subspecialty Collections

Permissions \& Licensing

Reprints including high resolution figures, can be found at: http://nn.neurology.org/content/8/3/e967.full.html

This article cites 9 articles, 1 of which you can access for free at: http://nn.neurology.org/content/8/3/e967.full.html\#\#ref-list-1

This article has been cited by 1 HighWire-hosted articles: http://nn.neurology.org/content/8/3/e967.full.html\#\#otherarticles

This article, along with others on similar topics, appears in the following collection(s):

All Immunology

http://nn.neurology.org//cgi/collection/all_immunology All Oncology

http://nn.neurology.org//cgi/collection/all_oncology

Transverse myelitis

http://nn.neurology.org//cgi/collection/transverse_myelitis

Information about reproducing this article in parts (figures,tables) or in its entirety can be found online at:

http://nn.neurology.org/misc/about.xhtml\#permissions

Information about ordering reprints can be found online: http://nn.neurology.org/misc/addir.xhtml\#reprintsus

Neurol Neuroimmunol Neuroinflamm is an official journal of the American Academy of Neurology.

Published since April 2014, it is an open-access, online-only, continuous publication journal. Copyright

Copyright (C) 2021 The Author(s). Published by Wolters Kluwer Health, Inc. on behalf of the American

Academy of Neurology.. All rights reserved. Online ISSN: 2332-7812.

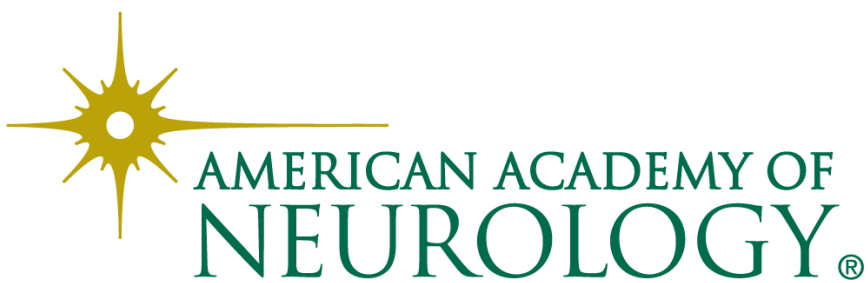

